\title{
The Influence of Renminbi Internationalization on the Chinese Stock Market
}

\author{
Yang-chao WANG ${ }^{1, a}$, Jui-jung TSAI ${ }^{1, b,{ }^{*}}$ and Bing-xin $\mathrm{ZHOU}^{2, \mathrm{c}}$ \\ ${ }^{1}$ Newhuadu Business School, Minjiang University, Fuzhou 350108, China \\ ${ }^{2}$ The University of Sydney, NSW 2006, Australia \\ awangyangzhao@nbs.edu.cn, ${ }^{\text {b} c a i r u i r o n g @ n b s . e d u . c n, ~}{ }^{c}$ alisa.w.larson@gmail.com
}

Keywords: RMB Internationalization, Stock Market, GARCH Model.

\begin{abstract}
Along with the growth of the Chinese economy, China is apt to have increasingly significant position in the global markets. It's always one key for China to win a pivotal position among nations by internationalizing the currency. Several acts during this process, including accepting the market-linked exchange rate and expanding pilot cities of cross-border yuan settlement, would have direct or indirect impacts on the domestic financial markets by all means. The measures on perfecting marketization like carrying out RQDII, RQFII, and Shanghai-Hong Kong Stock Connect policies have also powered the speed of RMB internationalization through capital market internationalization. In order to see the differences between strategies the government took in different phase, we probed those particular effects on the stock market by using GARCH models. The results indicate that the government and the public media play an essential role in China unlike any other countries.
\end{abstract}

\section{Introduction}

Between November 2014 and July 2015, the severe fluctuation happened in the Chinese stock market captured worldwide attention. The Shanghai and Shenzhen stock indices were more than doubled the rate all the way for less than 7 months, following with a roughly $32 \%$ and $38 \%$ reductions within 27 days respectively. On the other hand, the tortuous experience for renminbi (RMB) internationalization also witnessed a similar trend to some extent. The potential attitude revealed for admitting RMB as a member of SDR by IMF was from a warm welcome to a temporary delay.

It is always one key for China to play a pivotal position among nations by RMB internationalization. In recent years, many measures on perfecting marketization such as RQDII, RQFII, and Shanghai-Hong Kong Stock Connect policies have powered the speed of RMB internationalization through capital market internationalization. Although the Chinese authorities still placed restrictions on the use of the currency and the development of the capital markets [1], China has basically achieved the objectives of cross-border direct investments and global financing by the end of 2014 [2]. For examples, the use of the RMB has been expanded from trade settlement to bond issuance denomination [3] in other countries. Promoting policies including RQFII and Shanghai-Hong Kong Stock Connect allowed foreign investments to enter the Chinese markets [4], further gaining the RMB worldwide acceptance. As RMB can be used to trade and invest in many offshore markets now, the currency is also internationalized by the market participants [5]. Furthermore, in 2014, China, the world's largest creditor, held more than $\$ 3.84$ trillion in foreign exchange reserve, strengthening its call for internationalization of the RMB [6]. 
The process of currency internationalization in China has distinct impact on the domestic capital markets, especially on the stock market. Therefore, our study is born under this background. This study provides a reference for regulators to develop the stock market and prevent its excessive volatility. In addition, it offers a new perspective for global investors when they think about the intrinsic causes of current features in the Chinese stock market to control risks. The issue becomes increasingly important along with the emerging investment opportunities in China. We use GARCH (generalized autoregressive conditional heteroscedasticity) models to investigate the specific influences on the stock market in different stages of the RMB internationalization.

\section{Literature Review}

As China has been devoted to pushing the process of RMB internationalization in recent years by various policies and projects, it goes without saying that the whole financial atmosphere was affected. In addition to those conventional considerations such as the macroeconomic flexibility and exchange rate risk, the process can enhance China's political power among nations [7]. It is the crucial objective which China strives for.

In July 2009, to forward the goal, the Chinese government launched the Pilot Program of RMB Settlement for Cross-border Trade Transactions. From then on, the RMB began to gain popularity in China's neighboring economies [3]. For examples, in 2015, the authority took new measures like OBAOR (One Belt And One Road) and AIIB (Asian Infrastructure Investment Bank) to carry forward the RMB worldwide acceptance. Based on this context, those neighboring economies together with other collaborating countries are further encouraged to use RMB, promoting its demands among nations.

Meanwhile, many scholars provide the suggestions to facilitate the use of RMB in other countries or regions like loosening capital account restrictions and deepening the forming mechanism of the interest rate. Among them, a liberalized interest rate regime and a free floating exchange rate system are always important characteristics of international currency [8].

Furthermore, $\mathrm{Xu}$ and $\mathrm{Li}$ [4] compared the IMF official reserves of the US dollar, the British pound, and the Japanese yen from 1987 to 2010 with their respective stock market developments to analogize the relationship between RMB internationalization and China's stock market development. Similarly, He and Li [9] analyzed the international competitiveness of the three currency. They both find that the domestic stock market can be motivated when the currency can gain a competitive edge in worldwide locations [4,9]. However, the conclusion is completely depend on the 3 developed market economy countries. The situations may not be the same for emerging economies [10], particularly for China. China's special market conditions are totally different from any other markets around the world.

\section{Data and Methodology}

Data for policy implementations are hand-collected from official news releases. Table 1 shows the policy events related to RMB internationalization from July 2009 to August 2015.

Trading data for the stock indices and the stock index futures are obtained from Wind. We calculate the daily yield returns of the Shanghai Composite index and the Shanghai 
Table 3. Model selection process

\begin{tabular}{lclccc}
\hline Models & \multicolumn{1}{c}{$m$} & \multicolumn{1}{c}{$\alpha_{1}$} & $\alpha_{2}$ & $\beta_{1}$ & $\beta_{2}$ \\
\hline GARCH$(1,1)$ & $0.445737 * * *$ & $0.093165 * * *$ & & $0.005047 *$ & \\
& $(0.029713)$ & $(0.003324)$ & - & $(0.003450)$ & - \\
GARCH $(1,2)$ & $0.765262 * * *$ & $-0.032488 * * *$ & & $0.003820 * *$ & $0.018654 * *$ \\
& $(0.061009)$ & $(0.002269)$ & - & $(0.002010)$ & $(0.002493)$ \\
GARCH $(2,1)$ & $0.567241 * * *$ & $-0.069989 * * *$ & $-0.014283 * * *$ & $-0.006131 * *$ & \\
& $(0.069148)$ & $(0.002300)$ & $(0.003497)$ & $(0.003471)$ & - \\
GARCH(2,2) & $0.220634 * * *$ & $-0.080813 * * *$ & 0.002747 & $-0.005754 *$ & $0.065231 * * *$ \\
& $(0.008211)$ & $(0.002636)$ & $(0.003263)$ & $(0.003820)$ & $(0.003340)$ \\
\hline
\end{tabular}

$$
\sigma_{t}^{2}=m+\sum_{i} \alpha_{i} \sigma_{t-i}^{2}+\sum_{j} \beta_{j} \epsilon_{t-j}^{2} .
$$

In addition to the conventional variables in the GARCH model, we further use the exogenous variable, $P_{k}$, to indicate the implementation period of a specific policy. It makes $\pi_{k}$ capture the policy impact on volatility. Moreover, $f_{t}$ is a control variable, controlling for the effect of the stock index futures. Therefore, the complete model form is shown in Eq. 2.

$$
\sigma_{t}^{2}=m+\sum_{i} \alpha_{i} \sigma_{t-i}^{2}+\sum_{j} \beta_{j} \epsilon_{t-j}^{2}+\sum_{k} \pi_{k} P_{k}+\vartheta f_{t} .
$$

\section{Empirical Analysis}

The results of the implementations of the policies are detailed in Table 4. We give brief explanations of these policies as follows. After the US dollar came under attack from the 2008 financial crisis, the RMB started its international process in July 1, 2009 when the cross-border RMB settlement scheme came into operation. It brought something for Chinese exporters to think about this signal of a new beginning. The new system would save costs for those international enterprises substantially. The A shares rose steeply in the next 4 days as a feedback of the good news, though it has also swelled the volatility and sensitized the trading environment. However, due to the global crisis the Chinese stock market was in a slump from then on.

\begin{tabular}{|c|c|c|c|}
\hline Date & $\pi_{k}$ & Date & $\pi_{k}$ \\
\hline 2009-07-01 & $\begin{array}{l}0.07189 \text { **** } \\
(0.01201)\end{array}$ & 2014-11-17 & $\begin{array}{l}0.10327 * * \\
(0.05987)\end{array}$ \\
\hline 2014-06-17 & $\begin{array}{l}0.04564 * * * \\
(0.01131)\end{array}$ & $2015-01-28$ & $\begin{array}{l}0.02069 * * \\
(0.01154)\end{array}$ \\
\hline 2014-06-19 & $\begin{array}{l}0.04519 * * * \\
(0.01153)\end{array}$ & 2015-02-01 & $\begin{array}{c}0.03317 * \\
(0.02315)\end{array}$ \\
\hline 2014-11-04 & $\begin{array}{l}0.02944 * * * \\
(0.01209)\end{array}$ & 2015-06-29 & $\begin{array}{c}0.01199 \\
(0.01268)\end{array}$ \\
\hline 2014-11-05 & $\begin{array}{l}0.02708^{* *} * \\
(0.01190)\end{array}$ & $2015-07-28$ & $\begin{array}{c}0.00772 \\
(0.01725)\end{array}$ \\
\hline 2014-11-06 & $\begin{array}{l}0.02611 * * \\
(0.01182)\end{array}$ & 2015-08-05 & $\begin{array}{c}0.00976 \\
(0.01778)\end{array}$ \\
\hline 2014-11-08 & $\begin{array}{l}0.02578 * * \\
(0.01179) \\
\end{array}$ & 2015-08-06 & $\begin{array}{c}0.00632 \\
(0.01960) \\
\end{array}$ \\
\hline$m$ & $\alpha$ & $\beta$ & $\vartheta$ \\
\hline $\begin{array}{l}0.02752 \text { *** } \\
(0.00697)\end{array}$ & $\begin{array}{l}0.82676 \text { **** } \\
(0.01119)\end{array}$ & $\begin{array}{l}0.12644 * * * \\
(0.01144)\end{array}$ & $\begin{array}{l}-0.02118 \\
(0.02694)\end{array}$ \\
\hline
\end{tabular}

Table 4. The effects of policy implementations 
Not until the middle of 2014 when the China Construction Bank is appointed as the clearing bank for RMB business in London and Frankfurt, RMB has received further bigger approval. Meanwhile, the China Foreign Exchange Trade System was authorized by the PBC to perfect direct trading measures between RMB and pound through the foreign exchange market among banks. Leading to a chance to further reduce exchange costs, this news enliven the domestic stock market.

Then the timeline flow to November 2014, policies related to RQDII, RQFII and Shanghai-Hong Kong Stock Connect have been presented one after another. The stock market shows fluctuations. In addition, the news concerning two-way cross-border RMB cash pooling also excited the market. This is not a strange reaction because this pooling was born for those multinational businesses to transfer their spared cash to brunches abroad, instead of investing the domestic stock market. In other words, partial funds would be guided to foreign markets via this policy.

In this stage, many investors viewed the next step of opening-up policies regarding the capital markets optimistically. From regional to global scales, the authority enacted relative policies to promote capital and equity swap among countries would become cornerstones for RMB to be added into the reserve currency list.

On January 28, 2015, RMB won the fifth position in most ordinary payment currency and on February 1, OBAOR Construction Working Conference is hold in Beijing, All these acts said express same words: RMB internationalization is on the way. On June 29, the signing ceremony of AIIB is hold in Beijing. Though various factors upset the overall trend of the market, officially launched AIIB has clearly heated the investing community and lifted the stock market for a while.

On July 28, 2015, IMF restates for the second time in the last decade that RMB is not underestimated any more, our currency has been affirmed officially. In addition, on August 5, IMF announces to extend the term of validity for SDR till 30 September, 2016. All kinds of these good news has seemed to convey an undoubted message to investors that our currency has the great chance to get the 5th position of SDR (This position has finally gained on December 1st, 2015).

On August 6, 2015, the first RQFII in the Americas enters into the mainland China's capital markets, served by the Hong Kong and Shanghai Banking Corporation (HSBC). Following the pace of RMB moving toward Americas, the stock market eased the continuous haze and slightly recovered in the next day.

\section{Conclusions}

In this study, we investigate how the process of currency internationalization impacts the domestic stock market in China between July 2009 and September 2015. By means of GARCH models, the results not only demonstrate that there exists the close connection between the RMB internationalization and stock market evolvement, but also find that relevant policies have distinct influences on the stock market in different stages. The effects are particularly significant in the stage of the capital market internationalization in 2014. Most policies in this stage had a positive trend and were generally accepted among investors.

After fostering a favorable circumstance home and abroad for RMB expansion plan, with several landmark policies, China has opened the mainland market step by step to make RMB become a global currency. Totally speaking, RMB internationalization together with the further progress of domestic capital markets have clearly played the 
role to promote China's economy development. Furthermore, the government has laid the groundwork for the RMB as one of the major reserve currencies.

\section{Acknowledgement}

This research was financially supported by the Natural Science Foundation of Fujian Province, China (Grant No. 2017J01800 and 2016J05174), the Specialized Research Fund of Higher Education of Fujian Province, China (Grant No. JK2015039), and the Research Project for Young and Middle-Aged Faculty of Fujian Province, China (Grant No. JAS160403 and JAS150479).

\section{References}

[1] W. Dobson, P.R. Masson, Will the renminbi become a world currency? China Economic Review, 2009, 20(1) 124-135.

[2] Y. Xiong, Shanghai-Hong Kong Stock Connect: Capital account liberalization in China. The Chinese Banker, 2014, 12 83-85.

[3] H. Gao, Convertibility as a step for the RMB internationalization, Economic Change and Restructuring, 2013, 46(1) 71-84.

[4] C. $\mathrm{Xu}, \mathrm{H} . \mathrm{Li}$, Empirical research on interaction movements between currency internationalization and stock market development, Journal of Finance and Economics, 2012(07) 13-17.

[5] R.N. McCauley, Renminbi internationalisation and China's financial development, Journal of Chinese Economic and Business Studies, 2013, 11(2) 101-115.

[6] E. Kwon, China's monetary power: Internationalization of the Renminbi, Pacific Focus, 2015, 30(1), 78-102.

[7] H. Chey, Can the Renminbi rise as a global currency? Asian Survey, 2013, 53(2) 348-368.

[8] F. Liu, Y. Zheng, Current situation and promoting strategies of Renminbi internationalization, 2012 Second International Conference on Business Computing and Global Informatization, IEEE, 2012, 335-338.

[9] W. He, H. Li, The influence of currency internationalization on the international competitiveness of the stock market: Evidence from USA, Japan, and UK, Journal of Finance and Economics, 2013(09) 41-45.

[10] R. Levine, S.L. Schmukler, Internationalization and stock market liquidity, Review of Finance, 2006, 10(1) 153-187. 